\title{
Analisis kemampuan komunikasi matematis tertulis dalam menyelesaikan masalah matematika ditinjau dari gaya kognitif siswa kelas VIII SMP
}

\author{
Yolita Malaya ${ }^{1 *}$, Nyoman Sridana ${ }^{2}$, Hapipi ${ }^{3}$, Sudi Prayitno ${ }^{4}$ \\ ${ }^{1}$ Mahasiswa Pendidikan Matematika, FKIP, Universitas Mataram, Mataram \\ 2,3,4 Pendidikan Matematika, FKIP, Universitas Mataram, Mataram \\ yolitamalaya@gmail.com \\ Diterima: 13-09-2021; Direvisi: 26-09-2021; Dipublikasi: 30-09-2021
}

\begin{abstract}
This study aims to analyze the written mathematical communication skills through the lence of cognitive style of the eighth-grade students of SMP Negeri 4 Praya Barat Daya in the academic year 2020/2021. With the subjects of research used is 4 students of class VIII A which is taken were in the form of GEFT test results. This study is a descriptive study. The instrument used is test GEFT and written mathematical communication skills test. The findings of the study showed that (a) Students with field-independent cognitivestyle depictedproper written mathematical communication skill. Students at this level were able to state ideas or mathematical solutions in their own language clearly and precisely, they also were able to state problems in the form of pictures, and were able to write down mathematical ideas and explanations correctly but were still not optimal. (b) Students with a field-dependent cognitive style had good mathematical communication ability. Students at this level were able to state ideas or mathematical solutions in their own language properlyyet are still incomplete, they were still not optimal in addressing problems in the form of images, and lastly, they werealso able to write mathematical ideas and explanations clearly and accurately.
\end{abstract}

Keywords: mathematical communication; cognitive style; problem solving.

\begin{abstract}
Abstrak
Penelitian ini bertujuan untuk menganalisis kemampuan komunikasi matematis tertulis ditinjau dari gaya kognitif siswa kelas VIII SMP Negeri 4 Praya Barat Daya tahun ajaran 2020/2021. Dengan subjek penelitian adalah 4 orang siswa kelas VIII A yang diambil berdasarkan hasil tes GEFT. Jenis penelitian ini adalah penelitian deskriptif. Adapun instrument yang digunakan adalah tes GEFT dan tes kemampuan komunikasi matematis. Dari hasil penelitian, didapatkan hasil: (a) Siswa dengan gaya kognitif field independent kemampuan komunikasi matematis tertulisnya baik. Siswa pada tingkat ini sudah dapat menyatakan idea tau solusi matematika dengan bahasa sendiri dengan jelas dan tepat, sudah mampu menyatakan permasalahan dalam bentuk gambar, dan sudah mampu menuliskan ide dan penjelasan matematika dengan tepat namun masih kurang sempurna. (b) Siswa dengan gaya kognitif field dependent kemampuan komunikasi matematisnya cukup baik. Siswa pada tingkat ini sudah dapat menyatakan idea tau solusi matematika dengan bahasa sendiri dengan baik namun masih kurang lengkap, masih belum sempurna dalam menyatakan permasalahan kedalam bentuk gambar dimana masih belum lengkap, dan sudah mampu menuliskan ide dan penjelasan matematika dengan jelas dan tepat.
\end{abstract}

Kata Kunci: komunikasi matematis; gaya kognitif; penyelesaian masalah.

\section{PENDAHULUAN}

Komunikasi matematis dapat diartikan sebagai kemampuan mengekspresikan ide dan proses matematika baik secara lisan maupun tulisan (Maulana, 2017). Lebih lanjut 
NCTM (2000) menyatakan bahwa komunikasi matematis adalah kemampuan menyampaikan ide-ide matematika dengan jelas, baik secara lisan maupun tulisan. Salah satu tujuan pembelajaran matematika adalah menuntut siswa untuk mampu melakukan komunikasi matematis (NCTM, 2000).

Kemampuan komunikasi matematis dapat berperan penting pada hard skill siswa, karena sifatnya yang universal sehingga dapat dipahami oleh setiap orang dan dapat digunakan dalam kehidupan sehari-hari (Hendriana, dkk, 2017). Hard skill matematis adalah penguasaan ilmu pengetahuan, teknologi dan juga keterampilan yang berhubungan pada bidang ilmunya, yang diturunkan dari kompetensi inti dan kompetensi dasar pada tingkat kelas yang bersangkutan. Pada dasarnya, kemampuan komunikasi merupakan kemampuan yang perlu dimiliki oleh dan dikembangkan pada siswa yang mempelajari matematika, karena matematika merupakan salah satu bidang ilmu yang berperan cukup penting dari sekian banyak bidang ilmu yang ada dan selalu mendapat prioritas untuk dikembangkan (Baidowi, dkk, 2019). Pernyataan tersebut juga dimuat dalam tujuan pendidikan nasional dan tujuan pembelajaran matematika di sekolah (Hidayat \& Sumarmo, 2013).

Siswa akan sulit memahami matematika tanpa adanya komunikasi yang baik sebagaimana tujuan proses pembelajaran yang sebelumnya ditetapkan dengan baik, karena proses komunikasi dapat membantu siswa dalam membangun berbagai macam makna seperti menyampaikan gagasan dengan benar, dan memudahkan dalam menjelaskan ide tersebut kepada orang lain sehingga informasinya dapat mudah dimengerti dan dipahami (Haerudin, 2013).

Berdasarkan hasil wawancara dengan guru matematika SMP Negeri 4 Praya Barat Daya di peroleh informasi bahwa, pada saat pembelajaran di kelas hanya terdapat beberapa siswa yang aktif mau menanggapi pertanyaan dari guru dan mau bertanya apabila menemui kesulitan ketika mengerjakan soal. Disamping itu, pada saat melakukan observasi pada tanggal 18 November 2019, diketahui bahwa kebanyakan dari siswa masih kurang tepat dalam menuangkan ide-ide matematis secara tertulis. Mereka merasa kebingungan jika diberikan soal yang berbeda dengan apa yang dicontohkan sebelumnya, ini disebabkan karena guru masih dominan dibandingkan dengan siswa saat proses pembelajaran, kemudian siswa masih kesulitan dalam memberikan penjelasan atau alasan dari setiap jawaban yang diberikannya terhadap soal atau permasalahan. Hal ini menandakan kurangnya kemampuan komunikasi matematis siswa, terutama kemampuan komunikasi matematis secara tertulis.

Dalam pembelajaran di kelas, diketahui juga bahwa setiap siswa memiliki cara yang berbeda-beda dalam menyerap maupun dalam memproses informasi yang didapatkannya dalam proses pembelajaran. Perbedaan tersebut memunculkan suatu ciri khas atau karakteristik. Perbedaan karakteristik antar siswa yang menetap dalam cara menyusun dan mengelola informasi serta pengalaman-pengalaman dikenal dengan gaya kognitif (Slameto, 2013). 
Salah satu gaya kognitif yang telah dipelajari secara meluas adalah Field Dependent (FD) dan Field Independent (FI). Seseorang siswa dikatakan memiliki gaya kognitif Field Dependent (FD) adalah ketika siswa tersebut mempersepsikan diri dipengaruhi oleh lingkungan. Sedangkan seseorang siswa dikatakan memiliki gaya kognitif Field Independent (FI) adalah ketika siswa tersebut mempersepsikan diri bahwa sebagian besar perilaku tidak dikuasai oleh lingkungan (Putriana, 2017).

Kemampuan komunikasi matematis pun berkaitan dengan gaya kognitif. Hal ini dikarenakan gaya kognitif berpengaruh terhadap pemrosesan informasi dalam otak siswa sehingga akan terjadi perbedaan penyampaian ide-ide matematis siswa pada masing-masing gaya kognitif. Setiap individu memiliki gaya kognitif yang berbeda-beda tidak terkecuali bagi siswa.

Di SMP Negeri 4 Praya Barat Daya telah melakukan pembelajaran tatap muka. Maka peneliti akan melakukan penelitian dengan judul "Analisis Kemampuan Komunikasi Matematis Tertulis dalam Menyelesaikan Masalah Matematika Ditinjau dari Gaya Kognitif Siswa Kelas VIII SMP”.

\section{METODE PENELITIAN}

Penelitian ini dilakukan di SMP Negeri 4 Praya Barat Daya pada kelas VIII semester genap tahun ajaran 2020/2021. Jenis penelitian yang digunakan dalam penelitian ini yaitu deskriptif. Menurut Darwis (2003), penelitian deskriptif dimaksudkan untuk mendeskripsikan secara sistematis dan akurat suatu situasi atau area populasi tertentu yang bersifat aktual. Populasi dalam penelitian ini adalah siswa kelas VIII A SMP Negeri 4 Praya Barat Daya yang berjumlah 28 siswa. Subjek penelitian terdiri dari 4 siswa yaitu 2 siswa dari kategori FI dan 2 siswa dari kategori FD. Teknik pengumpulan data dalam penelitian ini menggunakan teknik tes dan non tes. Teknik tes yaitu berupa tes group embedded figure test (GEFT) untuk menentukan gaya kognitif subjek, dan tes kemampuan komunikasi matematis tertulis. Teknik non tes berupa observasi dan wawancara. Sebelum soal tes kemampuan komunkasi matematis tertulis digunakan dilakukan uji validitas isi menggunakan rumus Aiken's V untuk mengetahui instrumen layak atau tidak digunakan. Formula Aiken's V yaitu:

$$
V=\frac{s}{[n(c-1)]}
$$

\footnotetext{
Keterangan:

$V=$ indeks validitas butir

$s=r-l_{0}$

$L_{0}=$ angka penilaian validitas terendah (misalnya 1$)$

$c=$ angka penilaian validitas tertinggi (misalnya 4)

$r=$ angka yang diberikan oleh penilai

$n=$ jumlah validator
} 
Dimana harga V ditunjukkan pada Tabel 1 berikut ini:

Tabel 1. Harga V untuk Menunjukkan Validitas Isi

\begin{tabular}{ll}
\hline Harga V & Keterangan \\
\hline $0,00-0,44$ & Kurang Valid \\
$0,45-0,71$ & Cukup Valid \\
$0,72-0,85$ & Valid \\
$0,86-1,00$ & Sangat Valid \\
\hline
\end{tabular}

Dalam penelitian ini teknik analisis data meliputi teknik analisis data Group Embedded Figure Test (GEFT), teknik analisis data hasil tes kemampuan komunikasi matematis, dan teknik analisis data hasil wawancara.

\section{HASIL DAN PEMBAHASAN}

Berdasarkan hasil tes GEFT siswa kelas VIII-F maka didapat 4 subjek sesuai kategori gaya kognitif seperti pada Tabel 2 berikut.

Tabel 2. Siswa Yang Terpilih Sebagai Subjek Penelitian Dari Hasil Tes GEFT

\begin{tabular}{cccc}
\hline No. & Kelompok Gaya Kognitif & Subjek & Nilai Tes GEFT \\
\hline 1. & FI - K & R-08 & 16 \\
2. & FI - L & R-14 & 12 \\
3. & FD - K & R-02 & 10 \\
4. & FD - L & R-24 & 6 \\
\hline
\end{tabular}

\subsection{Sub-bagian Hasil}

Pada penelitian ini, subjek untuk kemampuan komunikasi matematis dengan gaya kognitif field independent adalah R-08 dan R-14. Hasil analisis yang telah dilakukan dari kedua subjek, kemampuan komunikasi matematis tertulis siswa pada subjek bergaya kognitif field independent dapat dikategorikan dalam tingkat kemampuan komunikasi matematis tertulis yaitu pada kategori baik. Hal ini dikarenakan siswa yang bergaya kognitif field independent dapat menyatakan ide atau permasalahan matematika dengan bahasa sendiri dengan jelas dan tepat, sudah mampu menyatakan permasalahan dalam bentuk gambar,dan sudah mampu menuliskan ide dan penjelasan matematika dengan tepat namun masih kurang sempurna.

\subsection{Kemampuan Komunikasi Matematis Tertulis Siswa Bergaya Kognitif Field Dependent}

Pada penelitian ini, subjek untuk kemampuan komunikasi matematis dengan gaya kognitif field independent adalah R-02 dan R-24. Hasil analisis yang telah dilakukan dari kedua subjek, kemampuan komunikasi matematis siswa dengan gaya kognitif field dependent dapat dikategorikan dalam tingkat kemampuan komunikasi matematis tertulis yaitu pada kategori cukup baik. Hal ini dikarenakan subjek dengan gaya kognitif field dependent kurang mampu dalam menyatakan ide atau solusi permasalahan 
matematika dengan bahasa sendiri. karena subjek menuliskan apa yang diketahui dalam soal, tetapi kurang lengkap dalam menuliskan apa yang ditanyakan. Selain itu, subjek juga kurang mampu dalam menyatakan permasalahan dalam bentuk gambar, karena masih kurang lengkap dalam menggambarkan grafik koordinat kartesius untuk menyelesaikan soal. Serta kurang mampu dalam menggunakan bahasa matematika dalam mengekspresikan ide matematikanya. Akan tetapi subjek dengan gaya kognitif field dependent mampu menuliskam ide dan penjelasan dalam menyelesaikan permasalahan matematika secara benar dalam bentuk tulisan dalam menyelesaikan soal. Walaupun cara yang digunakannya masih terkesan menghafal dan kurang sistematis.

\section{SIMPULAN}

Berdasarkan analisis data dan pembahasan dapat ditarik kesimpulan sebagai berikut:

a) Siswa dengan gaya kognitif field independent kemampuan komunikasi matematis tertulisnya baik. Siswa pada tingkat ini sudah dapat menyatakan idea tau solusi matematika dengan bahasa sendiri dengan jelas dan tepat, sudah mampu menyatakan permasalahan dalam bentuk gambar, dan sudah mampu menuliskan ide dan penjelasan matematika dengan tepat namun masih kurang sempurna.

b) Siswa dengan gaya kognitif field dependent kemampuan komunikasi matematisnya cukup baik. Siswa pada tingkat ini sudah dapat menyatakan idea tau solusi matematika dengan bahasa sendiri dengan baik namun masih kurang lengkap, masih belum sempurna dalam menyatakan permasalahan kedalam bentuk gambar dimana masih belum lengkap, dan sudah mampu menuliskan ide dan penjelasan matematika dengan jelas dan tepat.

\section{REFERENSI}

Baidowi, B., Amrullah, A., \& Hikmah, N. (2019). Peningkatan Hasil Belajar Matematika Siswa Kelas VIII SMPN 13 Mataram Tahun Ajaran 2017/2018 Melalui Lesson Study. Mandalika Mathematics and Education Journal, 1(1), 1-12. https://doi.org/10.29303/jm.v1i1.537

Darwis, D. (2003). Metode Penelitian Kebidanan, prosedur,Kibijakan, dan Etik. Jakarta: Buku Kedokteran EGC.

Haerudin, H. (2013). Pengaruh Pendekatan SAVI Terhadap Kemampuan Komunikasi dan Penalaran Matematik serta Kemandirian Belajar Siswa SMP. Infinity Journal, 2(2), 183-193.

Hendriana, H., Rohaeti, E. E., \& Sumarmo, U. (2017). Hard Skills dan Soft Skills Matematik Siswa. Bandung: Refika Aditama.

Hidayat, W., \& Sumarmo, U. (2013). Kemampuan Komunikasi dan Berpikir Logis Matematik Serta Kemandirian Belajar. Jurnal Delta-Fi, 2(1), 1-14.

Maulana. (2017). Konsep Dasar Matematika dan Pengembangan Kemampuan Berpikir Kritis-Kreatif. Sumedang: UPI Sumedang Press.

NCTM. (2000). Principles and Standards for School Mathematics. In The National Council of Teachers of Mathematics, Inc. The National Council of Teachers of Mathematics, Inc.

https://www.cambridge.org/core/product/identifier/S0007125000082039/type/journal_article 
Malaya, dkk.

Analisis kemampuan komunikasi ...

Putriana, Y. (2017). Analisis Kemampuan Komunikasi Matematis Berdasarkan Gaya Kognitif Siswa SMA. Ekuivalen, 29(2).

Slameto, S. (2013). Belajar dan Faktor-Faktor yang Mempengaruhi. Jakarta: Rineka Cipta. 